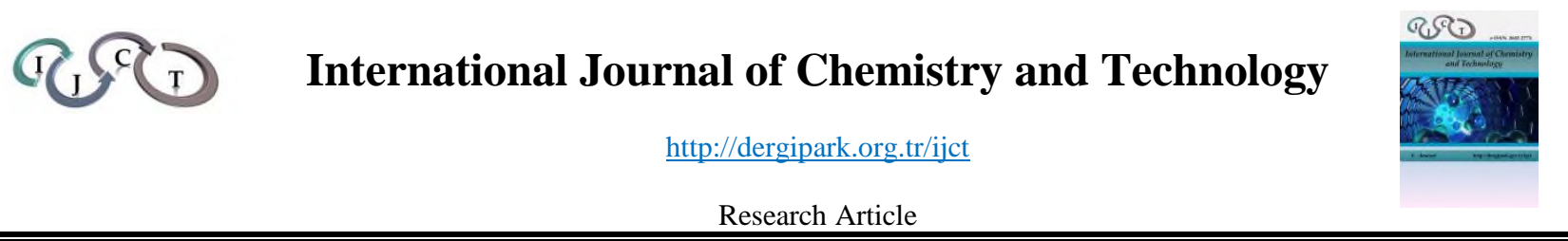

\title{
Synthesis, spectral characterization, DFT, and molecular docking studies of 2 - ((2,3- Dihydrobenzo [b] [1,4] dioxin-6-yl) (1H-indol-1-yl) methyl) phenol compound
}

\author{
Yeliz ULAŞ ${ }^{1, *}$ \\ ${ }^{1}$ Uludağ University, Faculty of Arts \& Sciences, Department of Chemistry, Bursa, 16000, Turkey
}

Received: 27 May 2021; Revised: 16 September 2021; Accepted: 19 September 2021

*Corresponding author e-mail: yelizulas@uludag.edu.tr

Citation: Ulaş, Y. Int. J. Chem. Technol. 2021, 5 (2), 133-140.

\section{ABSTRACT}

Synthesis of an alkylaminophenol compound used as a drug active material was carried out and the structural analysis of the compound was investigated experimentally and theoretically. For theoretical calculations, DFT / B3LYP method and 6-311 $++\mathrm{G}(\mathrm{d}, \mathrm{p})$ set were used. Many properties of the compound; Spectral data, bond length, bond angle, dihedral angles, thermodynamic parameters, molecular surface, FMO analysis, nonlinear optical (NLO) properties and Natural Bond Orbital analysis were theoretically investigated. Also, a molecular docking study shows that the title compound might exhibit inhibitory activity against $2 \mathrm{RAW}$ protein.

Keywords: Alkylaminophenol, DFT, molecular docking, NBO, NLO

\section{INTRODUCTION}

Alkylaminophenols are heterocyclic compounds containing hydroxyl and nitrogen in their structure..$^{1-4}$ It is found in the structures of drugs frequently used in cancer treatments. The compounds having antioxidant activity enables them to be used in chemotherapy.

Although there are compounds synthesized in this field in recent years, the diversity of cancer types also accelerates the synthesis of new bioactive compounds. In addition, the fact that the radicals formed as a result of cancer cells become neutral and have antioxidant properties increase the importance of this compound
2- ((2,3-Dihidrobenzo [b] [1,4] dioksin-6-il) (1H-indol-1-il) metil) fenol bileşiğinin sentez, spektral karakterizasyon, DFT ve moleküler docking çalışmaları

ÖZ

İlaç etken maddesi olarak kullanılan bir alkilaminofenol bileşiğinin sentezi gerçekleștirilmiş ve bileșiğin yapısal analizi deneysel ve teorik olarak incelenmiştir. Teorik hesaplamalar için DFT / B3LYP yöntemi ve 6-311 ++ G (d, p) seti kullanılmıştır. Bileşiğin birçok özelliği; Spektral veriler, bağ uzunluğu, bağ açısı, dihedral açılar, termodinamik parametreler, moleküler yüzey, FMO analizi, doğrusal olmayan optik (NLO) özellikler ve Natural Bond Orbital analizi teorik olarak incelenmiştir. Ayrıca, moleküler doking çalışmaları, başlık bileşiğinin 2RAW proteinine karş1 inhibitör aktivite sergilediğini göstermektedir.

Anahtar Kelimeler: Alkilaminofenol, DFT, molekülar docking, NBO, NLO

class. Although there are many methods in the literature for the synthesis of alkylaminophenols, the method using the petasis reaction was preferred in this study. ${ }^{7-11}$ The reaction takes place by the amine and carbonyl compounds forming iminium ion and removing boric acid from the boronate complex formed by the added boronic acid. Studies on theoretical investigations of these compounds with quantum chemical calculations in the literature are quite limited. ${ }^{12}$

In order to ensure the diversity of alkylaminophenol type compounds, a new compound was synthesized in the study and then many properties of this compound were examined theoretically. Gaussian 09W software was 
used for theoretical calculations and DFT/B3LYP/6$311++\mathrm{G}(\mathrm{d}, \mathrm{p})$ set was preferred for calculations. ${ }^{13-15}$ Also, its biological significance was investigated by examining its effects on $2 \mathrm{RAW}$ protein with molecular docking studies.

\section{MATERIALS AND METHODS}

2.1 Experimental and Calculation methods

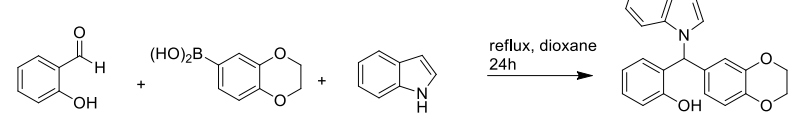

Figure 1. Synthesis of Alkylaminophenol Compound.

Synthesis was carried out according to the procedure in the literatüre (Figure1). ${ }^{5}$

The chemicals used for synthesis were used directly without any extra purification. Structure analysis of the synthesized compound has been made by Bruker FT-IR spectrometer and Agilent $600 \mathrm{MHz}$ NMR spectrometers. 2 - ((2,3-Dihydrobenzo [b] [1,4] dioxin-6-yl) (1H-indol1-yl) methyl) phenol: Verim $0.313(87 \%)$, red brown solid, MP $75-76{ }^{\circ} \mathrm{C} .{ }^{1} \mathrm{H} \mathrm{NMR}\left(600 \mathrm{MHz}, \mathrm{CDCl}_{3}\right): \delta(\mathrm{ppm})$ $=2.07(\mathrm{~s}, 1 \mathrm{H}$, indole $), \quad 3.72(\mathrm{~s}, 1 \mathrm{H}$, indole $), 4.15-4.20$ (m,4H,dioxin), $5.58(\mathrm{~s}, 1 \mathrm{H}, \mathrm{CH}) ; 5.79(\mathrm{~s}, 1 \mathrm{H}, \mathrm{Ar}-\mathrm{OH})$, 6.63-6.68 (m,3H, Ar- $\underline{H}), 6.76-6.88$ (m, 3H, Ar- - ), 7.14$7.21(\mathrm{~m}, 2 \mathrm{H}, \mathrm{Ar}-\underline{\mathrm{H}}), 7.30$ (s, 1H, Ar- $\underline{\mathrm{H}}), 8.03$ (s, 1H, Ar$\mathrm{H}), 8.08(\mathrm{~s}, 1 \mathrm{H}, \mathrm{Ar}-\mathrm{H}) \cdot{ }^{13} \mathrm{C}(\mathrm{CDCl} 3,150 \mathrm{MHz}): \delta=21.1$ (indole); 42.3 (indole); 60.6 (dioxin); 67.6 (chiral carbon), 102.4 (Ar-); 111.1(Ar-), 116.1 (Ar-); 116.9 (Ar); 117.1 (Ar-); 117.2 (Ar-); 119.5 (Ar-); 119.9 (Ar-); 120.6 (Ar-); 122.3 (Ar-); 123.7 (Ar-); 124.0 (Ar-); 126.8 (Ar-); 130.0 (Ar-); 136.6 (Ar-); 142.1 (Ar-); 143.3 (Ar-); 153.5

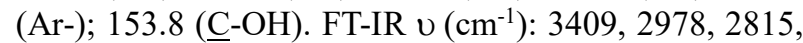
$1705,1589,1501,1453,1281,1254,1190,956,825$.

After the experimental characterization of structural, some properties of the compound was calculated with theoretical methods. Calculations include the B3LYP theory and 6-311 ++ G (d,p) set which is composed of Becke's three-parameter energy-functional hybrid approac and Lee-Yang and Parr's correlation function ${ }^{16}$ in the Gaussian 09W program. Gauss-View 5.0 program was used for molecular modelling. ${ }^{17}$

\section{RESULTS AND DISCUSSION}

\subsection{Molecular Geometry}

The optimization process of the title compound synthesized using the Petasis reaction was carried out using the B3LYP / 6-311 ++ G (d, p) base set. The optimized form of the compound is given in Figure 2.

The bond length, bond angles and dihedral angles of the compound are comparatively given in Table 1.

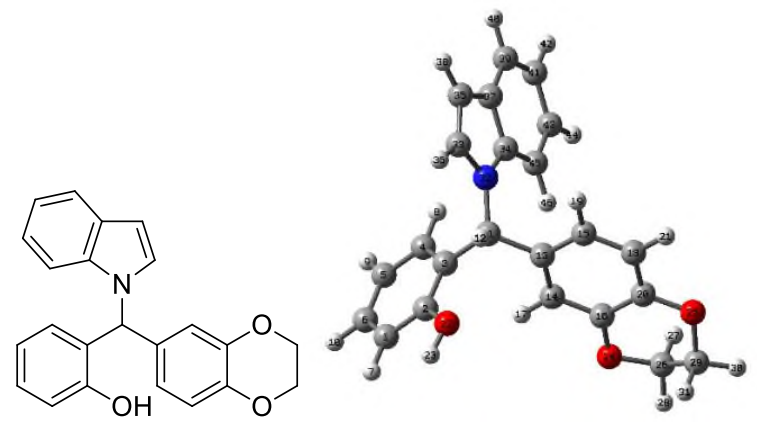

(a)

(b)

Figure 2. Molecular structure(a) and Optimized form(b) of 2 ((2,3-Dihydrobenzo [b] [1,4] dioxin-6-yl) (1H-indol-1-yl) methyl) phenol compound.

Table 1. Some selected geometric parameters of Alkylaminophenol.

\begin{tabular}{|c|c|c|c|}
\hline $\begin{array}{l}\text { Bond } \\
\text { Lenght }\left(\mathbf{A}^{0}\right)\end{array}$ & B3LYP & Bond Angles $\left({ }^{0}\right)$ & B3LYP \\
\hline $\mathrm{C} 1-\mathrm{C} 2$ & 1.3947 & C4-C3-C11 & 123.1 \\
\hline $\mathrm{C} 2-\mathrm{C} 3$ & 1.4038 & $\mathrm{C} 11-\mathrm{C} 3-\mathrm{C} 2$ & 119.0 \\
\hline $\mathrm{C} 3-\mathrm{C} 4$ & 1.3956 & $\mathrm{C} 2-\mathrm{O} 22-\mathrm{H} 23$ & 109.8 \\
\hline $\mathrm{C} 4-\mathrm{C} 5$ & 1.3942 & C2-C1-H7 & 119.7 \\
\hline C5-C6 & 1.3919 & C1-C6-C5 & 119.9 \\
\hline C4-H8 & 1.0827 & H12-C11-C13 & 105.6 \\
\hline $\mathrm{C} 1-\mathrm{H} 7$ & 1.0864 & C13-C15-H19 & 119.9 \\
\hline $\mathrm{C} 2-\mathrm{O} 22$ & 1.3726 & C13-C14-H17 & 121.4 \\
\hline $\mathrm{O} 22-\mathrm{H} 23$ & 0.9627 & C13-C14-C16 & 120.8 \\
\hline $\mathrm{C} 3-\mathrm{C} 11$ & 1.5263 & C16-C20-C18 & 119.3 \\
\hline C11-H12 & 1.0933 & C20-C18-H21 & 118.4 \\
\hline $\mathrm{C} 11-\mathrm{C} 13$ & 1.5324 & $\mathrm{C} 20-\mathrm{C} 16-\mathrm{O} 24$ & 121.8 \\
\hline N32-C33 & 1.3863 & $\mathrm{C} 16-\mathrm{O} 24-\mathrm{C} 26$ & 113.8 \\
\hline N32-C34 & 1.3905 & $\mathrm{O} 25-\mathrm{C} 29-\mathrm{C} 26$ & 110.2 \\
\hline C34-C37 & 1.4246 & $\mathrm{O} 24-\mathrm{C} 26-\mathrm{H} 27$ & 109.5 \\
\hline C33-C35 & 1.3661 & $\mathrm{H} 28-\mathrm{C} 26-\mathrm{C} 29$ & 111.3 \\
\hline C11-N32 & 1.4707 & C11-N32-C34 & 129.7 \\
\hline C37-C39 & 1.4042 & C11-N32-C33 & 122.2 \\
\hline C34-C45 & 1.4001 & N32-C33-H36 & 119.6 \\
\hline $\mathrm{C} 45-\mathrm{C} 43$ & 1.3884 & N32-C34-C45 & 131.3 \\
\hline C39-C41 & 1.3857 & C34-C45-H46 & 121.6 \\
\hline C33-H36 & 1.0794 & C45-C43-H44 & 119.1 \\
\hline $\mathrm{C} 45-\mathrm{H} 46$ & 1.0813 & C43-C41-C39 & 120.7 \\
\hline C13-C14 & 1.3911 & C41-C39-C37 & 119.2 \\
\hline C13-C15 & 1.4011 & C37-C34-C45 & 121.3 \\
\hline C15-H19 & 1.0841 & C37-C35-C33 & 106.8 \\
\hline C14-H17 & 1.0829 & Dihedral Angles & \\
\hline C20-C16 & 1.3995 & N32-C11-C3-C4 & 30.6 \\
\hline $\mathrm{C} 16-\mathrm{O} 24$ & 1.3753 & $\mathrm{~N} 32-\mathrm{C} 11-\mathrm{C} 3-\mathrm{C} 2$ & -148.4 \\
\hline $\mathrm{C} 20-\mathrm{O} 25$ & 1.3739 & $\mathrm{C} 11-\mathrm{C} 3-\mathrm{C} 2-\mathrm{O} 22$ & -0.1 \\
\hline $\mathrm{O} 24-\mathrm{C} 26$ & 1.4294 & $\mathrm{H} 23-\mathrm{O} 22-\mathrm{C} 2-\mathrm{C} 1$ & 0.3 \\
\hline $\mathrm{O} 25-\mathrm{C} 29$ & 1.4294 & N32-C11-C13-C14 & 79.6 \\
\hline $\mathrm{C} 26-\mathrm{C} 29$ & 1.5174 & N32-C11-C13-C15 & 55.1 \\
\hline C29-H30 & 1.0907 & $\mathrm{C} 16-\mathrm{O} 24-\mathrm{C} 26-\mathrm{C} 29$ & 45.6 \\
\hline $\mathrm{C} 25-\mathrm{H} 27$ & 1.0966 & $\mathrm{H} 30-\mathrm{C} 29-\mathrm{O} 25-\mathrm{C} 20$ & 165.7 \\
\hline
\end{tabular}


The O-H bond length was experimentally and theoretically found to be $0.96 \AA$. While N32-C11 bond length was experimentally 1.47 , it was calculated as 1.47 $\AA$ with the B3LYP method. In addition, the $\mathrm{C}=\mathrm{C}$ bond length of $1.37 \AA$ was calculated as $1.40 \AA$ (B3LYP) for $\mathrm{C} 13=\mathrm{C} 15$ atoms. Besides, the $\mathrm{C}-\mathrm{O}-\mathrm{H}$ bond angle, known to have an angle of $109.5^{\circ}$, was calculated as $109.8^{\circ}$ by the B3LYP method for C2-O22-H23. As a result; It can be said that there is a good agreement between the experimental bond length and bond angle values and the calculated values (Table 2 ).

\subsection{NMR Studies}

First of all, ${ }^{1} \mathrm{H}-\mathrm{NMR}$ and ${ }^{13} \mathrm{C}-\mathrm{NMR}$ values of the title compound were calculated with B3LYP / 6-311G $++(\mathrm{d}, \mathrm{p})$. Then chemical shift values in $\mathrm{CHCl} 3$ solvent medium and calculated by GIAO-NMR approach and IEFPCM method were compared with experimental values.

Table 2. Experimental and calculated ${ }^{1} \mathrm{H}$ and ${ }^{13} \mathrm{C}$ NMR chemical shifts (ppm).

\begin{tabular}{|l|l|l|}
\hline Atoms & Experimental & $\begin{array}{l}\mathbf{B 3 L Y P} \\
\left(\mathbf{C H C l}_{3}\right)\end{array}$ \\
\hline H23 & 5.79 & 4.39 \\
\hline H12 & 5.58 & 7.16 \\
\hline H27-H28 & & \\
H30-H31 & $4.15-4.20$ & 4.19 \\
\hline H36 & 3.72 & 7.5 \\
\hline C35 & 21.1 & 105.5 \\
\hline C33 & 42.3 & 136.5 \\
\hline C26-C29 & 60.6 & 67 \\
\hline C13 & 136.6 & 140.2 \\
\hline C3 & 117.2 & 133.5 \\
\hline C11 & 67.6 & 65.0 \\
\hline C2 & 153.8 & 159.5 \\
\hline & & \\
\hline
\end{tabular}

$\mathrm{H} 12$ and $\mathrm{H} 23$ peaks, which are one of the characteristic peaks of the compound, were experimentally observed at $5.58 \mathrm{ppm}$ and 5.79, respectively, while calculations with the B3LYP method were found to be $7.16 \mathrm{ppm}$ and 4.39 ppm. While our chiral carbon $\mathrm{C} 11$ was experimentally seen at 67.4 , it was found to be 65.0 in our theoretical calculations.

In addition, the $\mathrm{C} 2$ carbon to which the hydroxyl group is attached has experimentally been found to have a value of $153.8 \mathrm{ppm}$, while theoretically, it has a value of 159.5 ppm. Although there are some deviations due to the presence of the $\mathrm{OH}$ group in the structure and intramolecular hydrogen bonds, it can be said that our theoretical data are compatible with the experimental data.

\subsection{Mulliken Charge}

The most common of the population analysis methods is the mulliken charge distribution. It is often used to make some qualitative estimates of the structure. Analysis; it was carried out with the B3LYP / 6-311G ++ (d, p) method and the results are given in Table 3. Mulliken charges are between-0.710 and 0.710 . When we look at the atomic charges of alkylaminophenol, it is seen that the negative charge is around C39, C34, C11, C14, C5, $\mathrm{C} 41$ and $\mathrm{C} 6$ atoms, and the positive charge is around the N32, C3, C37, C13, H17, H23 atoms.

Tablo 3. Mulliken charges of the studied molecule.

\begin{tabular}{|l|c|c|c|}
\hline Atoms & $\begin{array}{c}\text { Mulliken } \\
\text { (B3LYP) }\end{array}$ & Atoms & $\begin{array}{c}\text { Mulliken } \\
\text { (B3LYP) }\end{array}$ \\
\hline C11 & -0.517 & C15 & -0.138 \\
\hline C3 & 0.473 & O25 & -0.135 \\
\hline C2 & -0.144 & O24 & -0.1 \\
\hline O22 & -0.194 & N32 & 0.710 \\
\hline H23 & 0.266 & C33 & 0.051 \\
\hline C1 & -0.228 & H17 & 0.269 \\
\hline C5 & -0.422 & C34 & -0.528 \\
\hline C6 & -0.320 & C37 & 0.469 \\
\hline C13 & 0.351 & C39 & -0.592 \\
\hline C14 & -0.424 & C41 & -0.364 \\
\hline
\end{tabular}

\subsection{Frontier Molecular Orbitals (FMO)}

FMO tells us about the reactivity of the compound. In order to determine the relevance of the compound to chemical reactions, we need to determine the energy values of the HOMO and LUMO orbitals. The structures showing the energy difference between HOMO and LUMO for our compound are given in Figure 3. HOMO and LUMO energies were calculated as -5.5287 and 0.7252 , respectively. In this case, the $\Delta \mathrm{E}$ energy difference is also calculated as $4.8035 \mathrm{eV}$. Physicochemical parameters of the compound by using HOMO and LUMO energy values are given in Table 4.

Table 4. HOMO, LUMO, $\Delta \mathrm{E}$, electronegativity $(\chi)$ chemical hardness $(\eta)$, softness $(S)$ and electrophilic index $(\chi)$ values of 2 - ((2,3-Dihydrobenzo [b] [1,4] dioxin-6-yl) (1H-indol-1-yl) methyl) phenol compound.

\begin{tabular}{|l|c|}
\hline $\begin{array}{l}\text { Physicochemical } \\
\text { parameters }\end{array}$ & B3LYP/6-311++G(d,p) \\
\hline $\mathrm{E}(\mathrm{HOMO}, \mathrm{eV})$ & -5.5287 \\
\hline $\mathrm{E}(\mathrm{LUMO}, \mathrm{eV})$ & -0.7252 \\
\hline$\Delta \mathrm{E}(\mathrm{eV})$ & 4.8035 \\
\hline$\chi$ & 3.1270 \\
\hline$\eta$ & 2.4018 \\
\hline $\mathrm{s}$ & 1.2009 \\
\hline$\omega$ & 4.0711 \\
\hline
\end{tabular}




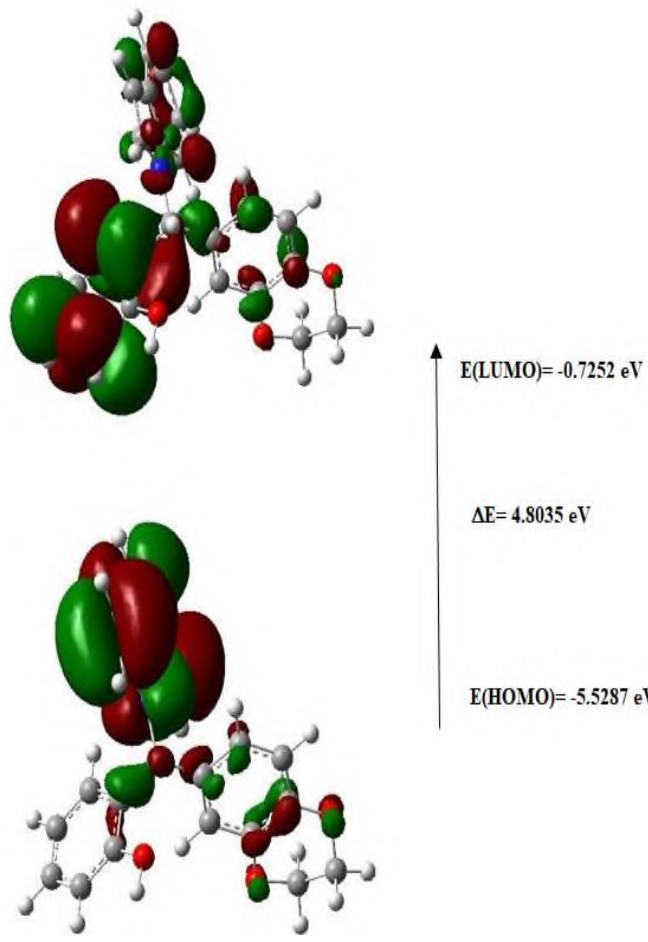

Figure 3. Frontier molecular orbitals, HOMO-LUMO energies.

\subsection{Molecular Electrostatic Potential (MEP)}

When looking at the three-dimensional molecular electrostatic potential surface of the compound (Figure 4 ), the energy scale is +6.476 e- 2 a.u. and between -6.476 e-2 a.u. These values are; gives information about the chemical behaviour of the molecule. Looking at the structure, it is seen that the negative charge is concentrated around the hydroxyl group and the positive part is concentrated on the nitrogen and phenyl protons. Determination of MEP surfaces; It is important in terms of providing information about intermolecular interactions and biological properties.

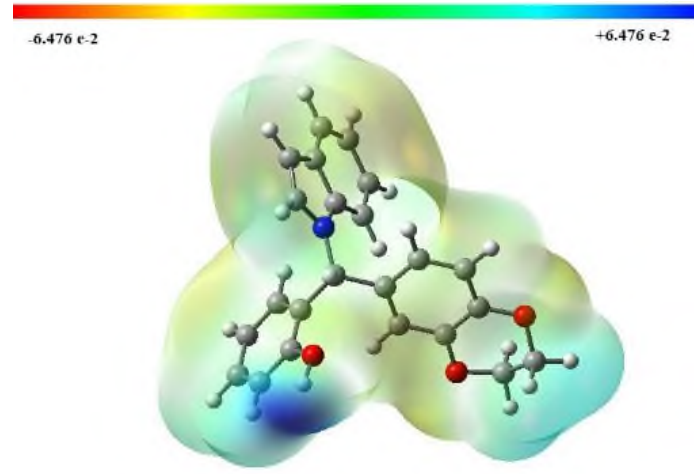

Figure 4. Molecular electrostatic potential surface and total electron density of 2 - ((2,3-Dihydrobenzo [b] [1,4] dioxin-6yl) (1H-indol-1-yl) methyl) phenol.

\subsection{Natural Bond Orbital (NBO) Analysis}

$\mathrm{NBO}$ analysis is used to determine the electron density in all orbitals of the molecule. ${ }^{18,19}$ A quadratic Fock matrix is used to evaluate the resulting donor-acceptor interactions. When each donor is defined as (i) and the recipient ( $\mathrm{j}$ ), delocalization is associated with $\mathrm{i} \rightarrow \mathrm{j}$, and the stability energy (E2) is expressed by the equation we define below. ${ }^{20}$

$\mathrm{E}(2)=\Delta \mathrm{E}_{\mathrm{i}, \mathrm{j}}=\mathrm{q}_{\mathrm{i}}\left[\mathrm{F}_{(\mathrm{i}, \mathrm{j})}{ }^{2}\right] /\left[\mathrm{E}_{\mathrm{i}}-\mathrm{E}_{\mathrm{j}}\right]$

Table 5. NBO analysis using a quadratic Fock matrix for selected chemical bonds.

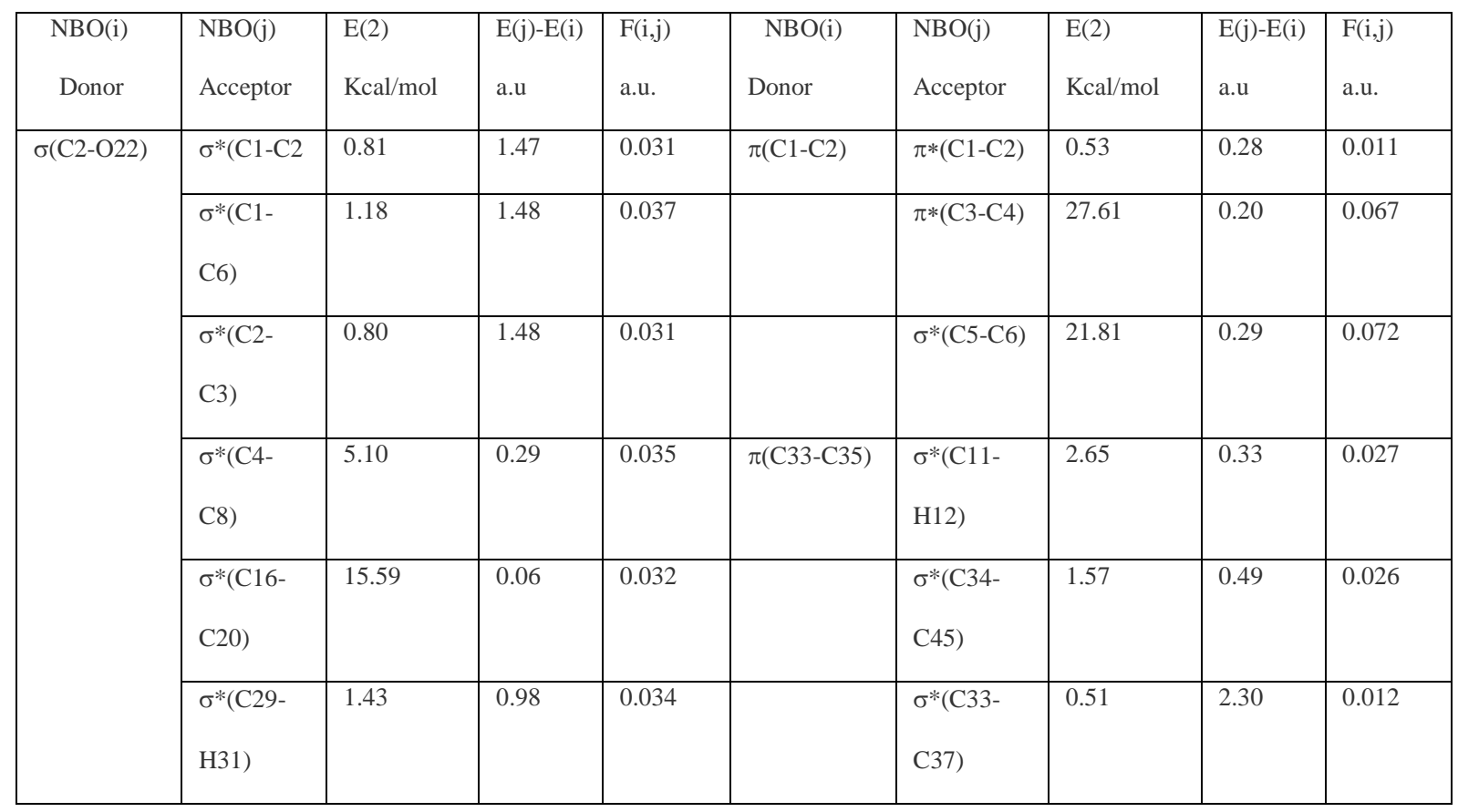


Table 5. Continued

\begin{tabular}{|c|c|c|c|c|c|c|c|c|c|}
\hline \multirow[t]{8}{*}{$\sigma(\mathrm{C} 3-\mathrm{C} 11)$} & $\begin{array}{l}\sigma^{*}(\mathrm{~N} 32- \\
\mathrm{C} 33)\end{array}$ & 1.09 & 1.08 & 0.031 & \multirow[t]{6}{*}{$\sigma(\mathrm{C} 33-\mathrm{C} 35)$} & $\sigma^{*}(\mathrm{C} 4-\mathrm{C} 8)$ & 212.67 & 0.07 & 0.109 \\
\hline & $\begin{array}{l}\sigma^{*}(\mathrm{C} 4- \\
\mathrm{H} 8)\end{array}$ & 5900.53 & 0.01 & 0.226 & & $\begin{array}{l}\sigma^{*}(\mathrm{C} 11- \\
\mathrm{N} 32)\end{array}$ & 16.76 & 0.43 & 0.076 \\
\hline & $\begin{array}{l}\sigma^{*}(\mathrm{C} 26- \\
\mathrm{H} 27)\end{array}$ & 25.83 & 0.65 & 0.116 & & $\begin{array}{l}\sigma^{*}(\mathrm{C} 29- \\
\mathrm{H} 31)\end{array}$ & 9.99 & 0.75 & 0.077 \\
\hline & $\begin{array}{l}\sigma^{*}(\mathrm{C} 29- \\
\mathrm{H} 31)\end{array}$ & 51.55 & 0.69 & 0.169 & & $\begin{array}{l}\sigma^{*}(\mathrm{C} 26- \\
\mathrm{H} 27)\end{array}$ & 5.03 & 0.71 & 0.033 \\
\hline & $\begin{array}{l}\sigma^{*}(\mathrm{C} 34- \\
\mathrm{C} 5)\end{array}$ & 3.15 & 0.82 & 0.048 & & $\begin{array}{l}\sigma^{*}(\mathrm{C} 39- \\
\mathrm{C} 41)\end{array}$ & 8.18 & 0.06 & 0.021 \\
\hline & $\begin{array}{l}\sigma^{*}(\mathrm{C} 34- \\
\mathrm{C} 45)\end{array}$ & 7.45 & 0.87 & 0.072 & & $\begin{array}{l}\sigma^{*}(\mathrm{C} 45- \\
\mathrm{H} 46)\end{array}$ & 14.90 & 0.24 & 0.031 \\
\hline & $\begin{array}{l}\sigma^{*}(\mathrm{C} 43- \\
\mathrm{C} 45)\end{array}$ & 11.04 & 0.22 & 0.048 & \multirow[t]{3}{*}{ LP(1) O22 } & $\sigma^{*}(\mathrm{C} 1-\mathrm{C} 2)$ & 6.09 & 1.16 & 0.075 \\
\hline & $\begin{array}{l}\sigma^{*}(\mathrm{C} 45- \\
\mathrm{H} 46)\end{array}$ & 5.90 & 0.18 & 0.03 & & $\begin{array}{l}\pi^{*}(\mathrm{C} 43- \\
\mathrm{C} 45)\end{array}$ & 6.45 & 0.20 & 0.035 \\
\hline \multirow[t]{5}{*}{$\sigma(\mathrm{C} 11-\mathrm{C} 13)$} & $\begin{array}{l}\sigma^{*}(\mathrm{C} 45- \\
\mathrm{H} 46)\end{array}$ & 9.62 & 0.66 & 0.071 & & $\begin{array}{l}\sigma^{*}(\mathrm{C} 45- \\
\mathrm{H} 46)\end{array}$ & 6.90 & 0.17 & 0.030 \\
\hline & $\begin{array}{l}\sigma^{*}(\mathrm{C} 45- \\
\mathrm{H} 46)\end{array}$ & 3.14 & 1.05 & 0.051 & \multirow[t]{3}{*}{$\mathrm{LP}(2) \mathrm{O} 22$} & $\pi^{*}(\mathrm{C} 1-\mathrm{C} 2)$ & 26.28 & 0.35 & 0.093 \\
\hline & $\begin{array}{l}\sigma^{*}(\mathrm{C} 45- \\
\mathrm{H} 46)\end{array}$ & 2.05 & 0.84 & 0.037 & & $\pi *(\mathrm{C} 3-\mathrm{C} 4)$ & 0.50 & 0.27 & 0.011 \\
\hline & $\begin{array}{l}\sigma^{*}(\mathrm{C} 45- \\
\mathrm{H} 46)\end{array}$ & 51.05 & 0.19 & 0.095 & & $\begin{array}{l}\sigma^{*}(\mathrm{C} 11- \\
\text { N32) }\end{array}$ & 3.68 & 0.07 & 0.014 \\
\hline & $\begin{array}{l}\sigma^{*}(\mathrm{C} 45- \\
\mathrm{H} 46)\end{array}$ & 100.07 & 0.15 & 0.111 & \multirow[t]{3}{*}{ LP(1) O24 } & $\begin{array}{l}\sigma^{*}(\mathrm{C} 16- \\
\mathrm{C} 20)\end{array}$ & 4.50 & 1.09 & 0.063 \\
\hline \multirow[t]{4}{*}{$\sigma(\mathrm{C} 11-\mathrm{N} 32)$} & $\begin{array}{l}\sigma^{*}(\mathrm{C} 4- \\
\mathrm{C} 5)\end{array}$ & 5.88 & 0.90 & 0.025 & & $\begin{array}{l}\sigma^{*}(\mathrm{C} 29- \\
\mathrm{H} 31)\end{array}$ & 10.25 & 0.62 & 0.072 \\
\hline & $\begin{array}{l}\sigma^{*}(\mathrm{C} 4- \\
\mathrm{H} 8)\end{array}$ & 646.14 & 0.11 & 0.237 & & $\begin{array}{l}\pi^{*}(\mathrm{C} 43- \\
\mathrm{C} 45)\end{array}$ & 1.69 & 0.15 & 0.015 \\
\hline & $\begin{array}{l}\sigma^{*}(\mathrm{C} 11- \\
\mathrm{H} 12)\end{array}$ & 6.48 & 0.81 & 0.065 & \multirow[t]{2}{*}{$\mathrm{LP}(2) \mathrm{O} 24$} & $\begin{array}{l}\sigma^{*}(\mathrm{C} 45- \\
\mathrm{H} 46)\end{array}$ & 10683.23 & 0.04 & 0.569 \\
\hline & $\begin{array}{l}\sigma^{*}(\mathrm{C} 26- \\
\mathrm{H} 27)\end{array}$ & 23.54 & 0.75 & 0.119 & & $\begin{array}{l}\pi^{*}(\mathrm{C} 43- \\
\mathrm{C} 45)\end{array}$ & 5180.26 & 0.07 & 0.572 \\
\hline
\end{tabular}


Table 5. Continued

\begin{tabular}{|c|c|c|c|c|c|c|c|c|c|}
\hline & $\begin{array}{l}\sigma^{*}(\mathrm{C} 29- \\
\mathrm{H} 31)\end{array}$ & 34.51 & 0.79 & 0.148 & & $\begin{array}{l}\sigma^{*}(\mathrm{C} 35- \\
\mathrm{C} 37)\end{array}$ & 68.94 & 2.53 & 0.384 \\
\hline & $\begin{array}{l}\sigma^{*}(\mathrm{C} 43- \\
\mathrm{C} 45)\end{array}$ & 8.71 & 0.32 & 0.05 & & $\begin{array}{l}\sigma^{*}(\mathrm{C} 34- \\
\mathrm{C} 45)\end{array}$ & 119.08 & 0.73 & 0.270 \\
\hline \multirow[t]{4}{*}{$\mathrm{LP}(1) \mathrm{O} 25$} & $\begin{array}{l}\sigma^{*}(\mathrm{C} 43- \\
\mathrm{C} 45)\end{array}$ & 19797.48 & 2.17 & 5.885 & \multirow[t]{4}{*}{$\mathrm{LP}(2) \mathrm{O} 25$} & $\begin{array}{l}\sigma^{*}(\mathrm{~N} 32- \\
\mathrm{C} 34)\end{array}$ & 14853.90 & 2.28 & 5.201 \\
\hline & $\begin{array}{l}\pi^{*}(\mathrm{C} 43- \\
\mathrm{C} 45)\end{array}$ & 1916.29 & 6.09 & 3.300 & & $\begin{array}{l}\sigma^{*}(\mathrm{O} 24- \\
\mathrm{C} 26)\end{array}$ & 1437.84 & 4.73 & 2.227 \\
\hline & $\begin{array}{l}\sigma^{*}(\mathrm{C} 43- \\
\mathrm{H} 46)\end{array}$ & 2203.48 & 6.05 & 3.276 & & $\begin{array}{l}\sigma^{*}(\mathrm{C} 13- \\
\mathrm{C} 14)\end{array}$ & 2840.76 & 5.12 & 3.418 \\
\hline & $\begin{array}{l}\sigma^{*}(\mathrm{C} 34- \\
\mathrm{C} 37)\end{array}$ & 49110.31 & 0.93 & 6.049 & & $\begin{array}{l}\pi^{*}(\mathrm{C} 13- \\
\mathrm{C} 14)\end{array}$ & 32.19 & 6.54 & 0.448 \\
\hline
\end{tabular}

When NBO analysis results are examined, it is seen that the atoms with the highest E (2) value are O22, O24, O25 atoms. It has been demonstrated by the data that these atoms (Table 5) are in strong interaction with phenyl rings. It can also be said that the chiral $\mathrm{C} 11$ atom is in strong interaction with the indole ring and phenyl rings to which it is attached with the N32 atom.

\subsection{Nonlinear Optical Properties (NLO)}

The NLO properties of the compound are due to its electrons. The presence of conjugation or donor groups in the structure changes many properties of the compound. Theoretical calculations made for this purpose give information about the electronic properties of the compound. Calculations were made by selecting the $p$-nitroaniline compound used as a reference in the study. Isotropic linear polarization $\langle\alpha\rangle$, anisotropic linear polarization $\Delta \alpha$, first-order hyperpolarization $\langle\beta\rangle$ and total dipole moment $(\mu)$ values were calculated using the B3LYP method using the equations below. ${ }^{21}$

$$
\begin{aligned}
& \mu=\left(\mu_{\mathrm{x}}^{2}+\mu_{\mathrm{y}}^{2}+\mu_{\mathrm{z}}^{2}\right)^{1 / 2} \\
& <\alpha>=1 / 3\left(\alpha_{\mathrm{xx}}+\alpha_{\mathrm{yy}}+\alpha_{\mathrm{zz}}\right) \\
& \Delta \alpha=\left[1 / 2\left(\left(\alpha_{\mathrm{xx}}-\alpha_{\mathrm{yy}}\right)^{2}+\left(\alpha_{\mathrm{yy}}-\alpha_{\mathrm{zz}}\right)^{2}+\left(\alpha_{\mathrm{zz}}-\alpha_{\mathrm{xx}}\right)^{2}\right)\right]^{1 / 2} \\
& <\beta>=\left[\left(\beta_{\mathrm{xxx}}\right.\right. \\
& \left.\left.+\beta_{\mathrm{xyy}}+\beta_{\mathrm{xzz}}\right)^{2}+\left(\beta_{\mathrm{yyy}}+\beta_{\mathrm{xxy}}+\beta_{\mathrm{yzz}}\right)^{2}+\left(\beta_{\mathrm{zzz}}+\beta_{\mathrm{xxz}}+\beta_{\mathrm{yyz}}\right)^{2}\right]^{1 / 2}
\end{aligned}
$$

Table 6. NLO Analysis Results.

\begin{tabular}{|l|l|l|l|l|l|}
\hline Property & $\boldsymbol{p}$-NA & Alkylaminophenol & Property & $\boldsymbol{p}$ - NA & Alkylaminophenol \\
\hline$\mu_{x}$ & -7.4519 & 3.0798 & $\beta_{x x x}$ & -99.4560 & 178.3004 \\
\hline$\mu_{y}$ & -0.001 & 3.0908 & $\beta_{x y y}$ & 16.7004 & 9.9421 \\
\hline$\mu_{z}$ & 0.6869 & 0.1066 & $\beta_{x z z}$ & 12.9992 & 10.6264 \\
\hline$\mu$ & 7.48 Debye & 4.36 Debye & $\beta_{y y y}$ & -0.0012 & 118.0253 \\
\hline$\alpha_{x x}$ & -58.7480 & -142.3714 & $\beta_{x x y}$ & -0.0004 & -20.6859 \\
\hline$\alpha_{y y}$ & -53.2767 & -146.1486 & $\beta_{y z z}$ & 0.0001 & 7.9136 \\
\hline$\alpha_{z z}$ & -60.6128 & -152.3852 & $\beta_{z z z}$ & 0.4969 & -5.5628 \\
\hline$<\alpha>$ & $-8.52 \times 10^{-24} \mathrm{esu}$ & $-2.18 \times 10^{-23} \mathrm{esu}$ & $\beta_{x x z}$ & 12.9100 & 23.8653 \\
\hline$\Delta \alpha$ & $9.79 \times 10^{-25} \mathrm{esu}$ & \multirow{2}{*}{$1.3 \times 10^{-24} \mathrm{esu}$} & $\beta_{y y z}$ & 0.4172 & -5.5387 \\
\cline { 3 - 6 } & & $<\beta>$ & $8.99 \times 10^{-31} \mathrm{esu}$ & $1.95 \times 10^{-30} \mathrm{esu}$ \\
\hline
\end{tabular}

Looking at the NLO data (Table6); it is seen that the dipole moment value of our alkylaminophenol compound is lower than p-NA. However, it is seen that the value of isotropic linear polarization, anisotropic linear polarization and first-order hyperpolarization is two times greater than p-NA. Based on these data, the compound of 2 - ((2,3-Dihydrobenzo [b] [1,4] dioxin-6yl) (1H-indol-1-yl) methyl) phenol has very high NLO properties in optoelectronics, laser technology, optical It appears to be a new compound that will contribute to many areas such as data storage. 


\subsection{Molecular Docking}

Molecular docking studies were performed using Autodock Vina program. ${ }^{22}$ The binding sites were centred on the Protein (PDB ID: 2RAW). Molecular docking techniques demonstrated that alkylaminophenol compound is Centromere-associated protein inhibitör. When looking at the 2D diagram (Figure 5), it was seen that there were alkyl-pi alkyl interactions and hydrogen bonds between the ligand and the protein. It was determined that there were interactions at a distance of 4.37 and $4.58 \AA$ between alkyl and pi-alkyl. Hydrogen bond lengths were calculated to be $1.11,1.86,1.93$ and $2.03 \AA$, respectively. The settlement score of the compound was determined to be- $6.6 \mathrm{kcal} / \mathrm{mol}$. This value clearly indicates that the alkylaminophenol compound has good biological activity (Table 7).

Table 7. Molecular Docking Results for Alkylaminophenol compound.

\begin{tabular}{|c|c|c|c|c|}
\hline $\begin{array}{c}\text { Protein } \\
\text { ID }\end{array}$ & $\begin{array}{c}\text { Binding } \\
\text { Energy } \\
(\mathbf{K c a l} / \mathbf{m o l})\end{array}$ & $\begin{array}{c}\text { RMSD } \\
(\mathbf{\AA})\end{array}$ & Interactions & $\begin{array}{c}\text { Distance } \\
(\mathbf{\AA})\end{array}$ \\
\hline & & & & 1.11 \\
\cline { 4 - 5 } & & & ABN A:118 & 1.86 \\
\cline { 4 - 5 } & & \multirow{2}{*}{2.0} & & 1.93 \\
\cline { 4 - 5 } & & & LYS A:121 & 2.05 \\
\cline { 4 - 5 } & & & & 4.37 \\
\hline
\end{tabular}
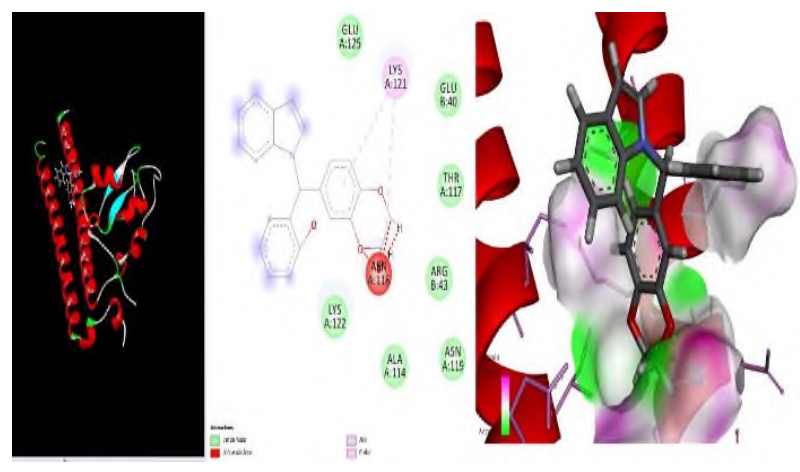

Figure 5. Docking analysis for the title compound.

\section{CONCLUSION}

In this study, the new alkylaminophenol type 2 - ((2,3Dihydrobenzo [b] [1,4] dioxin-6-yl) (1H-indol-1-yl) methyl) phenol compound was synthesized with high yield for the first time. Structural analyzes of the compound were carried out experimentally and theoretically. Theoretical calculations were made by considering the DFT / B3LYP method and the 6-311 ++ $\mathrm{G}(\mathrm{d}, \mathrm{p})$ base set. Many electronic properties of the compound (bond length, bond angle, dihedral angles) and the distribution of these electrons in orbitals (NBO) and chemical reactions have been calculated. Biological efficacy was predicted by molecular docking studies. In addition, it has been determined that NLO analysis can be effective in optoelectronics other than medical applications.

\section{Acknowledgements}

I would like to thank Melih ULAŞ for the optimization of the compound and Metin ULAŞ for bioinformatics contribution.

\section{Conflict of interests}

Author declare that there is no a conflict of interest with any person, institute, company, etc.

\section{REFERENCES}

1. Wu, P.; Givskov, M.; Nielsen, T. E. Chem. Rev., 2019, 119(20), 11245-11290

2. Neto, Í; Andrade, J.; Fernandes, A. S.; Pinto Reis, C.; Salunke, J. K.; Priimagi, A.; Candeias, N. R.; Rijo, P. ChemMedChem, 2016, 11, 2015-2023.

3. Takahashi, N.; Ohba, T.; Yamauchi, T.; \& Higashiyama, K. Bioorg. Med. Chem. 2006, 14(17), 6089-6096.

4. Liu, Y.; Wang, L.; Sui, Y.; Yu, J. Chin. J. Chem., 2010, 28(10), 2039-2044.

5. Ulaş, Y.; Özkan, A. İ.; Tolan, V. Ejosat, 2019, 16, 701706.

6. Doan, P.; Nguyen, T.; Yli-Harja, O.; Kandhavelu, M.; Yli-Harja, O.; Doan, P.; Nguyen, T.; Yli-Harja, O.; Candeias, N. R. Eur J Pharm Sci, 2017, 107, 208216.

7. Ulaş, Y. Ejosat, 2019, 16, 242-246.

8. Petasis, N. A.; Goodman, A.; Zavialov, I. A.. Tetrahedron, 1997, 53(48), 16463-16470.

9. Candeias, N. R.; Montalbano, F.; Cal, P. M. S. D.; Gois, P. M. P.. Chem. Rev., 2010, 110(10), 61696193.

10. Hosseinzadeh, R.; Lasemi, Z.; Oloub, M.; Pooryousef, M.. J. Iran. Chem. Soc., 2017, 14(2), 347-355.

11. Naskar, D.; Roy, A.; Seibel, W. L.; Portlock, D. E. Tetrahedron Lett., 2003, 44(31), 5819-5821.

12. Ulaş, Y. J. Comput. Biophys. Chem., 2021, 20(3), 323-335. 
13. Muthu, S.; E. Porchelvi, E.; Karabacak, M.; Asiri, A. M.; Swathi, S. S. J. Mol. Struct., 2015, 1081, 400412.

14. Suvitha, A; Periandy, S; Gayathri, P. Spectrochım Acta A, 2015, 138, 357-369.

15. Suvitha, A.; Periandy, S; Govindarajan, M; Gayathri, P. (2015). Spectrochım Acta A, 2015, 138, 900-912.

16. Becke, A. D. Physical Review A, 1988, 38(6), 30983100 .

17. Sivakumar, C.; Revathi, B.; Balachandran, V.; Narayana, B.; VinuthaV., S.; Shanmugapriya, N.; Vanasundari, K. J. Mol. Struct., 2021, 1224 129286

18. S. P. P. Leela, J.; Hemamalini, R.; Muthu, S.; AlSaadi, A. A. Spectrochım Acta A, 2015, 146, 177186.

19. Gültekin, Z.; Demircioğlu, Z.; Frey, W.; Büyükgüngör, O. J. Mol. Struct., 2020, 1199.

20. Ulaş, Y. Int. J. Chem. Technol. 2020, 4 (2), 138-145

21. Raja, M.; Raj Muhamed, R.; Muthu, S., Suresh, M. J. Mol. Struct., 2017, 1141, 284-298.

22. Subashini, K.; Govindarajan, R.; Surendran, R.; Mukund, K.; Periandy, S.; J. Mol. Struct., 2016, 1125, 576-591. 